\title{
Pesticide drift from aircraft applications with conical nozzles and electrostatic system
}

\author{
Deriva de agrotóxicos aplicados via aérea com sistema \\ eletrostático e bicos hidráulicos com pontas cônicas
}

\begin{abstract}
Alfran Tellechea Martini ${ }^{\text {* }}$ Luis Antonio de Avila ${ }^{\text {II }}$ Edinalvo Rabaioli Camargo ${ }^{\text {II }}$ Diogo Balbé Helgueira' ${ }^{I}$ Marlon Ouriques Bastiani ${ }^{I}$ Alci Enimar Loeck ${ }^{I I}$
\end{abstract}

ABSTRACT

Despite all advances obtained with the pesticide use worldwide and in Brazilian agriculture, there is still a lack of technologies for agricultural aircrafts. The objective of this study was to evaluate the drift produced by the use of conical nozzles and electrostatic system in aircraft application. The experimental design was completely randomized with a factorial arrangement and four replications. Treatments included two spraying equipment:

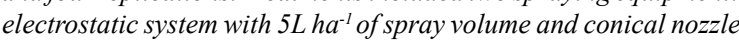

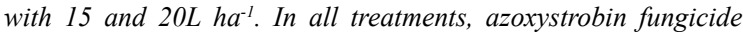
was used at a dose of $100 \mathrm{~g}$ a.i. $\mathrm{ha}^{-1}$ and paraffinic mineral oil at a dose of $0.5 \%$ v.v. Volume median diameter (VMD) and droplet density were estimated using water sensitive paper. Evaluations of drift distance were performed with glass collectors distributed horizontally on the soil surface, $50 \mathrm{~m}$ before the application band, at the application site and 12,5, 25, 50, 75, 100, 150, 200 and $300 \mathrm{~m}$ after the application site, along the wind direction. Azoxystrobin concentration in glasses were quantified by UHPLC-MS/MS. Results indicated that the drift distance can reach more than 300 meters away from the application site, with variable concentrations according to the equipment used. Electrostatic system reduced drift when compared to hydraulic conical nozzles.

Key words:

application technology, agricultural aircraft, electrostatic spraying, droplet spectrum, collectors.

RESUMO

Apesar dos avanços obtidos no uso de agrotóxicos na agricultura mundial e brasileira, ainda existe carência em tecnologias voltadas para aviação agrícola. O objetivo deste estudo foi avaliar a deriva ocorrida com a utilização de bicos hidráulicos com pontas cônicas e sistema eletrostático em aplicação aérea. $O$ delineamento experimental adotado foi inteiramente casualizado com quatro repetições. Os tratamentos foram compostos por dois equipamentos de pulverização: sistema eletrostático com volume

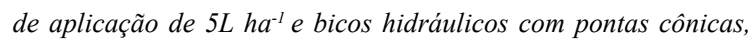

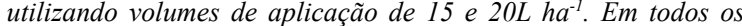
tratamentos, foi utilizado o fungicida azoxistrobina na dose de $100 \mathrm{~g}$ i.a. ha $a^{-1}$ e óleo mineral parafinico na dose de 0,5\% v.v. As avaliações de diâmetro mediano volumétrico e densidade de gotas foram realizadas através de papéis hidrossensiveis na faixa de aplicação. As avaliações de distância de deriva foram realizadas com coletores de vidro distribuídos horizontalmente sobre a superficie do solo, $50 \mathrm{~m}$ antes da faixa, na faixa de aplicação e aos 12,5, 25, 50, 75, 100, 150, 200 e 300m após a faixa de aplicação, no sentido da direção de vento. Azoxistrobina foi quantificada por UHPLC-MS/MS. Os resultados indicam que a distância de deriva pode alcançar mais de 300 metros do local de aplicação, com concentrações variáveis de acordo com o equipamento utilizado. $O$ sistema eletrostático reduz a deriva, quando comparado aos bicos hidráulicos com pontas cônicas.

Palavras-chave: tecnologia de aplicação, aviação agrícola, pulverização eletrostática, espectro de gotas, coletores.

\section{INTRODUCTION}

For a pesticide treatment to be effective, it depends not only on the chemical to be applied and amount of the active ingredient to be sprayed, but also on the uniformity and distribution on target surface. Thus, application technology has the function of distributing the product with suitable drop size for this target (RODRIGUES, 2010). With this need, equipment for air spraying of pesticides has been developed, primarily types of nozzle (conical and jet

\footnotetext{
'Programa de Pós-graduação em Fitossanidade (PPGFs), Universidade Federal de Pelotas (UFPel), 96010-900, Pelotas, RS, Brasil. E-mail: alfrantm@gmail.com. *Corresponding author.

IDepartamento de Fitossanidade, Universidade Federal de Pelotas (UFPel), Pelotas, RS, Brasil. 
plane hydraulic, electrostatic, screen rotary atomizers and disc rotary atomizers).

In traditional nozzles, which operate with hydraulic pressure, droplet formation is quite nonuniform, and this often prevents efficient implementation (CUNHA \& TEIXEIRA, 2001). Among the hydraulic nozzles used are the flat fan and the conical nozzle which work at lower pressures and use larger volumes of solution compared with the electrostatic system and rotary atomizers (BAYER et al., 2011).

Electrostatic spraying equipment differs from the others because it is a system which electrically charges the droplets generated by spray nozzles, causing migration to plants leaves by eletrostatic attraction (SCHRÖDER \& LOECK, 2006). Difference from this equipment compared to others available on the market is the drop diameter, which is $150 \mu \mathrm{m}$, and, after being generated by nozzles hydraulic energy, undergo an electrical charge, which causes them to be attracted by plants (SCHRÖDER, 2002).

Researches have been conducted for the development of new spraying equipment that enable the reduction of spray volume, hence reducing the cost, environmental contamination and providing a higher concentration of active ingredient to be sprayed on pests, rendering thereby a most effective control. Thus, the objective of this study was to evaluate the drift occurred when hydraulic conical nozzle and electrostatic system for aerial application are used.

\section{MATERIALS AND METHODS}

The study was conducted in the field, in a farm called "Granja 4 Irmãos" belonging to the group Joaquim Oliveira S/A, in partnership with the company "Taim Aero Agrícola", located in the municipality of Rio Grande/RS, in S32 $15^{\prime} 59,05^{\prime \prime}$ latitude - W52 33 '59,33" longitude and height of $7 \mathrm{~m}$. Treatments consisted of two spray equipment: electrostatic system with application volume of $5 \mathrm{~L} \mathrm{ha}^{-1}$ and hydraulic conical nozzle using application volume of 15 and $20 \mathrm{~L} \mathrm{ha}^{-1}$. In all treatments, azoxystrobin fungicide was used at a dose of $100 \mathrm{~g}$ a.i. ha $^{-1}$ and paraffinic mineral oil at a dose of $0.5 \%$ v.v., with water as carrier.

Evaluations of volumetric median diameter and drops density were done using water sensitive papers, which were distributed to each meter on the application range being fixed horizontally on a wooden surface, over the soil. Posteriorly, the evaluations were performed with Agroscan ${ }^{\circledR}$ software, which allows determination of variables.

To evaluate the drift distance as well as the concentration of pesticide in each sampling point, glass collectors were distributed horizontally on the soil surface $(50 \mathrm{~m}$ before the band, on the application band and 12,5, 25, 50, 75, 100, 150, 200 and 300m) after the application band, aligned with the wind direction and perpendicular to the flight in a sample area of $20 \times 300 \mathrm{~m}$. Use of collectors in the $50 \mathrm{~m}$ before the application aimed to verify any possible losses of drops in the opposite direction to the wind. Collectors were dimensioned $0.1 \times 0.25 \mathrm{~m}$ according to the standard ASAE S561.1 (ASABE, 2004).

After applying treatments, the collectors were transferred to a closed environment in which the extraction of spray deposit was made, using $50 \mathrm{~mL}$ of acetonitrile. The extracted solution was kept in amber glass and stored under refrigeration. Subsequently, samples were sent to the Pesticide Residue Laboratory - LARP of Universidade Federal de Santa Maria (UFSM). Determination of pesticides was performed using ultra-high performance liquid chromatography coupled to mass spectrometry in series (UHPLC-MS/ MS) with a limit of detection (LOD) of $0,15 \mu \mathrm{g} \mathrm{L}^{-1}$ and limit of quantitation (LOQ) of $0,5 \mu \mathrm{g} \mathrm{L}^{-1}$.

The weather was monitored daily for a period of 30 days to ensure the achievement of favorable weather conditions and to choose the best moment for the experiment installation. During the experiment, the weather conditions were monitored during the application period, using two hygro-thermo-anemometers, of the brands Kestrel $4000^{\circledR}$ and Icel ${ }^{\circledR}$, which were calibrated before use. One of the equipment has been installed near the area of the experiment, which stored the data on relative humidity of the air, ambient temperature, wind speed and wind direction every minute. But the other was used manually during spraying to monitor changes during the execution of the work, ensuring that the treatments were performed with similar meteorological parameters.

The aircraft used was an Ipanema EMB-202 equipped with DGPS Satloc-M3 ${ }^{\circledR}$, winglet wing tip type, wind pump. By moving with a speed of $176 \mathrm{Km} \mathrm{h}^{-1}$ and flight height of $2.5 \mathrm{~m}$ above the target and application band set to $15 \mathrm{~m}$. When using the electrostatic system, the aircraft is configured with 44 spray nozzles and Teejet TXVK 6 type nozzles, bars angle of $180^{\circ}$, regulated to generate fine droplets of $467 \mathrm{kPa}$ system pressure, amperage of $300 \mu \mathrm{A}$ and voltage of $6.000 \mathrm{~V}$. On the left bar, droplets generated were negatively charged, while in the right bar they were positively charged. When using the hydraulic conical nozzle, the aircraft has been configured with 32 nozzles spray of the conical type Teejet D6 (45), bars angle of $90^{\circ}$, regulated to generate medium droplets, by using volume of $15 \mathrm{~L} \mathrm{ha}^{-1}$ used in the system pressure with $333 \mathrm{kPa}$. For the volume of $20 \mathrm{~L}$ $\mathrm{ha}^{-1}$ the pressure used was $433 \mathrm{kPa}$. 
After each treatment, one liter of the spray mixture was removed, to determine the concentration of the application; the amount collected was packed in amber flask, kept under refrigeration and sent to LARP for analysis according to the method described above.

After the evaluations, data were analyzed for normality and homoscedasticity. So, all variables were subjected to analysis of variance $(\mathrm{P} \leq 0.05)$. In case of significance, the means were analyzed by Tukey test $(\mathrm{P} \leq 0.05)$ regarding drift distance comparisons and by Duncan test $(\mathrm{P} \leq 0.05)$ for the volumetric medium diameter of comparisons and drops density.

\section{RESULTS AND DISCUSSION}

During the application using the hydraulic conical nozzle tip and application volume of $20 \mathrm{~L} \mathrm{ha}^{-1}$, recorded wind speed was above recommendation, for all treatments, during the period in which the droplets were deposit, recorded wind speed was above the recommendation, and the wind kept in constant direction (Figure 1). According to ANTUNIASSI (2012), the optimum climatic conditions for pesticide application are temperature up to $30^{\circ} \mathrm{C}$, relative humidity greater than $50 \%$ and wind speed up to $10 \mathrm{~km} \mathrm{~h}^{-1}$. However, in the region where the experiment was conducted, it is very windy, and it is often necessary to operate with stronger winds, limiting the recommendation at a speed of $15 \mathrm{~km} \mathrm{~h}^{-1}$ (SOSBAI, 2012).

The drift distance varied between treatments (Table 1). When comparing the equipment, it was observed that the highest percentage of azoxystrobin deposited on the application band occurred in the electrostatic system with application volume of $5 \mathrm{~L} \mathrm{ha}^{-1}$, when compared with conical nozzle with volumes of 15 and $20 \mathrm{~L} \mathrm{ha}^{-1}$, where the highest concentrations were observed at 12,5 and 25 meters after application range. This result can be explained by the fact that the droplet spectrum generated is very heterogeneous in a conventional application system (110 to $350 \mu \mathrm{m}$ ), which enables fine droplets, smaller than $150 \mu \mathrm{m}$ without electric charges, which are very prone to drift (SCHRÖDER, 2002).

Similar results were obtained by CALDWELL (2006) and ANTUNIASSI et al. (2012). The first author evaluates aerial application drift of the dye Rhodamine WT applied with screen rotary atomizer and impact deflector nozzles, up to $400 \mathrm{~m}$ downstream of the application band. He noted that, for both treatments, a small concentration in the last collection point was detected, similar to what was reported in this research. Still, ANTUNIASSI et al. (2012), when assessing drift of the dye Rhodamine WT in sugarcane, in which the aircraft carry conical nozzle type Teejet D8-46, set to generate average drops with a $250 \mu \mathrm{m}$

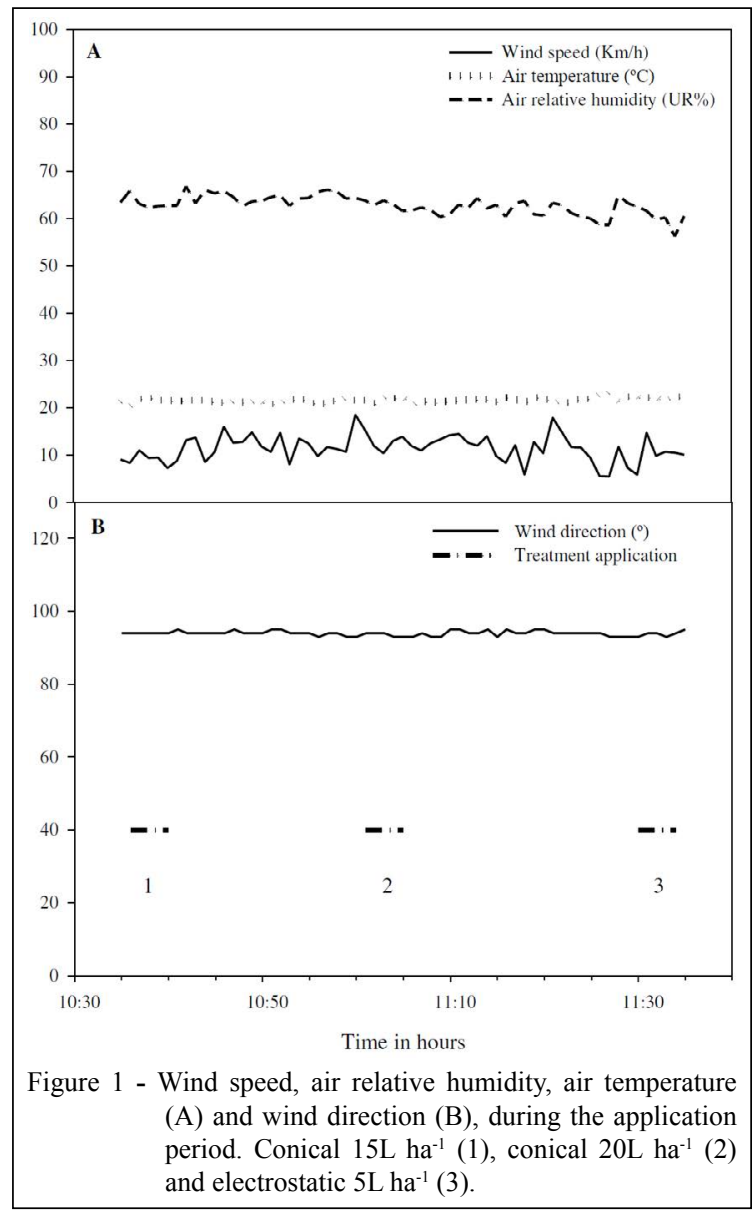

spectrum, they concluded that until the last sampled point $(2000 \mathrm{~m})$, the presence of the dye extracted from the deposit collector was detected.

Comparing the different equipment through the mass balance, there was a difference of data obtained by CALDWELL (2006), because the highest percentage of collection in the application band occurred for application performed with average drops, in which the equipment was calibrated to generate drops with a diameter of $250 \mu \mathrm{m}$, so that $91 \%$ of the total applied product were collected in the band. As for application using fine droplets, droplet spectrum of $200 \mu \mathrm{m}$, this percentage was lower, with a total collection of $59 \%$ of the amount applied. This differs from the results obtained in this study, because when using application with fine droplets (electrostatic $\left.5 \mathrm{~L} \mathrm{ha}^{-1}\right), 72 \%$ of the total applied was collected in the application band, while when using the system of conical nozzle, collected volume in the application band was approximately $7 \%$ for both volumes used.

These divergences can be explained by differences in weather conditions, topography,

Ciência Rural, v.46, n.9, set, 2016. 
Table 1 - Drift percentage of azoxystrobin (percentage of the amount of active ingredient collected), sprayed by air with electrostatic and conical equipments, represented by the mass balance of each treatment at collection points.

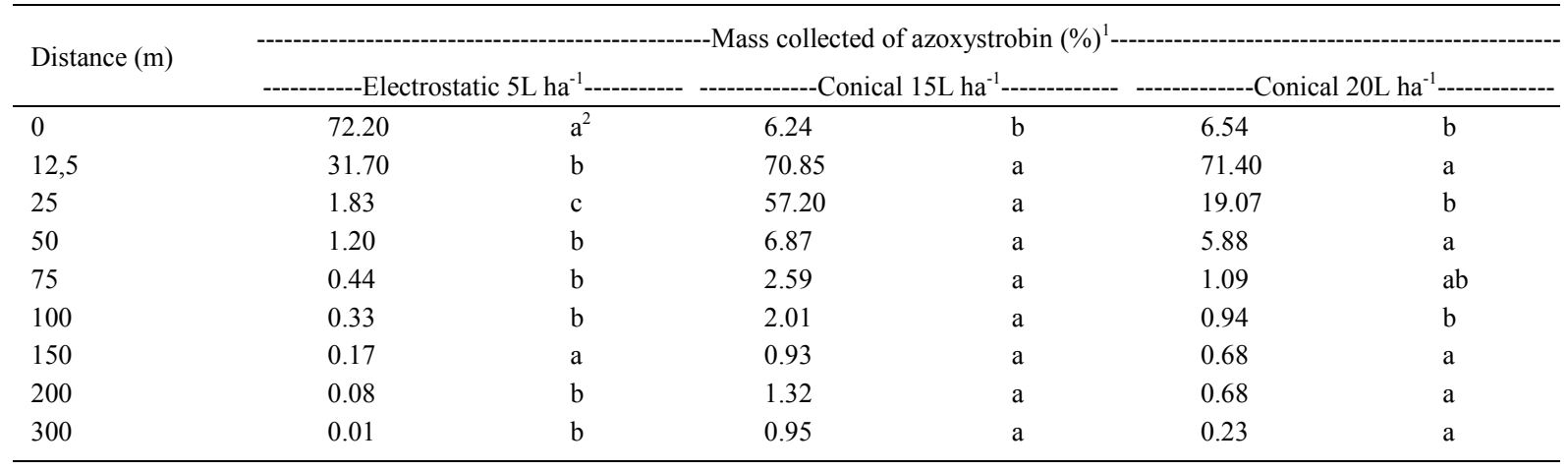

${ }^{1}$ The percentage drift were calculated by mass balance, in which it takes into account the concentration of active ingredient recovered by collectors regarding the concentration of the spray solution.

${ }^{2}$ Averages followed by same lowercase letters on the line do not differ by Tukey test at $5 \%$ probability.

but mainly by the specific characteristics of each equipment. Being that, when considering spraying with average drops, CALDWELL (2006) used impact deflecting nozzle, which generate a droplet spectrum less heterogeneous compared to the conical nozzle, which may explain the percentage difference recovered by collectors in the application range. However, when performing spray with fine droplets, the same author used rotary atomizer, which generates fine droplets uncharged, differing from the electrostatic system that generate electrically charged droplets (SCHRÖDER, 2002). The electrostatic system is characterized by generating electrically charged droplets with small droplets, which are strongly attracted by the target explaining the largest percentage collected in the application range and consequently reducing potential drift, reducing soil, water and atmosphere contamination (PATEL, 2015).

Therefore, for electrostatic charging be effective, besides the droplet diameter being of no more than 150 micrometers $(\mu \mathrm{m})$, which is in agreement with obtained in the study (Table 2), it is necessary that the amperage used is between 300 and $500 \mu \mathrm{A}$ and voltages between $6.000-9.000 \mathrm{~V}$, to prevent the charge/mass ratio $(\mathrm{Q} / \mathrm{M})$ is below the desired (SCHRÖDER, 2002). According to MASKI \& DURAIRAJ (2010), charge/ mass ratio $(\mathrm{Q} / \mathrm{M})$ is extremely important in electrostatic spraying, because it determines the relative ability of electric forces to overcome the forces of gravity and kinetic energy transmitted to drops.

In this way, it can be concluded that the system was properly calibrated, because the amperage used in this treatment was $300 \mu \mathrm{A}$ and voltage of $6.000 \mathrm{~V}$, which resulted in relation $\mathrm{Q} / \mathrm{M}$ of $0.81 \mathrm{mC} \mathrm{kg}^{-1}$.
Research demonstrates that for an application using electrostatic system to be efficient, the $\mathrm{Q} / \mathrm{M}$ ratio should be equal or larger than $0.8 \mathrm{mC}$ $\mathrm{kg}^{-1}$ (milicoulumb per kilogram of loaded liquid) as observed in this study. However, the occurrence of errors in the regulation of the equipment and amounts lower than $0.8 \mathrm{Mc} \mathrm{kg}^{-1}$ do not promote gains in the deposition of the drops on the target, and increases in the $\mathrm{Q} / \mathrm{M}$ ratio are directly proportional to the improvement in efficiency (SCHRÖDER, 2002; ZHAO et al., 2008).

For drops of density values (drops $\mathrm{cm}^{-2}$ ) and volumetric medianum diameter (VMD) there was a difference between the application equipment used (Table 2). Treatments using conical nozzle with application volume of 15 and $20 \mathrm{~L} \mathrm{ha}^{-1}$ generated higher densities to electrostatic and the minimum required of 20 drops $\mathrm{cm}^{-2}$ for a good coverage of target, levels that conform to recommended for the application of pesticides (SOSBAI, 2012).

Table 2 - Density and volumetric medianum diameter (VMD) droplets collected with water sensitive cards, generated by electrostatic and conical equipment for aerial application of azoxystrobin.

\begin{tabular}{lcc}
\hline Equipments & Density $($ drops cm & -2 \\
\hline Electrostatic 5 $\mathrm{L} \mathrm{ha}^{-1}$ & $13 \mathrm{c}^{1}$ & VMD $(\mu \mathrm{m})$ \\
Conical 15 $\mathrm{L} \mathrm{ha}^{-1}$ & $34 \mathrm{a}$ & $244 \mathrm{~b}$ \\
Conical 20L ha & $26 \mathrm{~b}$ & $250 \mathrm{a}$ \\
\hline
\end{tabular}

${ }^{1}$ Averages followed by same lowercase letters in the column do not differ by Duncan test at $5 \%$ probability. 
Considering the electrostatic system, the drop density was below minimum recommended for good coverage of the target, which is 20 drops $\mathrm{cm}^{-2}$, and this is probably because when the droplets are charged, it is required that the target is grounded to the soil, that makes electric exchanges with the soil, so there is attraction of the droplets sprayed, thus, as the water sensitive cards were fixed on flat wooden surfaces, these collectors had no electric charges to exchange with drops, reducing the efficacy of drops collection (SCHRÖDER \& LOECK, 2006).

The volumetric medianum diameter values are in agreement with those reported in the literature, with higher VMD values observed in treatments, where conical nozzle were used for both volumes. Conversely, VMD for the electrostatic system were significantly lower. The conical nozzle generate droplets with diameter less than $300 \mu \mathrm{m}$ (SOSBAI, 2012). The electrostatic system, by using higher pressure in the system produce smaller droplets, so the droplets produced are of $150 \mu \mathrm{m}$ to suit charge/ mass ratio (PASCUZZI \& CERRUTO, 2015). Following these premises, it can be concluded that the adjustment and calibration of the systems used were in accordance with what is described in the literature.

So, from the results of this study it can be concluded that the drift distance can reach more than 300 meters from the site of application, with variable concentrations according to the equipment used. Electrostatic system reduced drift when compared to hydraulic nozzles with conical nozzle.

\section{ACKNOWLEDGEMENTS}

To the Universidade Federal de Pelotas (UFPEL) by the availability of its structure and feasibility of research conducted. To the Public Bidding MCT/CNPq/MEC/CAPES/CTAGRO/CT-HYDRO/FAPS/EMBRAPA N. 22/2010 - Fundação de Amparo à Pesquisa e Inovação do Estado de Santa Catarina (FAPESC) - Conselho Nacional de Desenvolvimento Científico e Tecnológico (CNPq) - Contract 562451/2010-2. To Coordenação de Aperfeiçoamento de Pessoal de Nível Superior (CAPES) for financial support. To the enterprises "Taim Aero Agrícola" and "Granja 4 Irmãos", by the availability of equipment and structure to carry out the research.

\section{REFERENCES}

ANTUNIASSI, U.R. et al. Spray drift from aerial application on sugarcane. In: INTERNATIONAL CONFERENCE ON AGRICULTURAL ENGINEERING CIGR-AgEng 2012, Valência. Agriculture and engineering for a healthier life, v.1, p.1-6.

ANTUNIASSI, U.R. Tecnologia de aplicação: conceitos básicos, inovações e tendências. In: TOMQUELSKI, G.V. et al. (Eds.). Publicações fundação chapadão: soja e milho 2011/2012. 5.ed. Chapadão do Sul: Fundação Chapadão, 2012. Cap.16, p.113-139.
ASABE. Procedure for measuring drift deposits from ground, orchard, and aerial sprayers. St. Joseph, 2004. ASAE S 561.1.

BAYER, T. et al. Spraying equipment and rates of fungicide application in irrigated rice. Revista Brasileira de Engenharia Agrícola eAmbiental, v.15, n.2, p.192-198, 2011. Available from: <http://www.scielo.br/ scielo.php?pid $=\mathrm{S} 1415-43662011000200007 \&$ script $=$ sci arttext $>$. Accessed: Jun. 10, 2015. doi: 10.1590/S1415-43662011000200007.

CALDWELL, D.M. Quantification of spray drift from aerial applications of pesticide. 2006. 106f. Thesis (Master of Science in the Department of Plant Sciences) - University of Saskatchewan.

CUNHA, J.P.A.R.; TEIXEIRA, M.M. Technical characteristics of hydraulic fan spray nozzles. Revista Brasileira de Engenharia Agrícola e Ambiental, v.5, n.2, p.344-348, 2001. Available from: $<$ http://www.scielo.br/scielo.php?script=sci_arttext\&pid=S1415$43662001000200028 \& \operatorname{lng}=$ en $\& n r m=i s o \& t \operatorname{lng}=p t>$. Accessed: May 15, 2015. doi: 10.1590/S1415-43662001000200028.

MASKI, D.; DURAIRAJ, D. Effects of electrode voltage, liquid flow rate, and liquid properties on spray chargeability of an airassisted electrostatic-induction spray-charging system. Journal of Electrostatics, v.68, n.2, p.152-158, 2010. Available from: <http:// www.sciencedirect.com/science/article/pii/S0304388609002332>. Accessed: Dec. 21, 2015. doi: 10.1016/j.elstat.2009.12.001.

PASCUZZI , S.; CERRUTO, E. Spray deposition in "tendone" vineyards when using a pneumatic electrostatic sprayer. Crop Protection, v.68, p.1-11, 2015. Available from: <http://www. sciencedirect.com/science/article/pii/S0261219414003469>. Accessed: Dec. 21, 2015. doi: 10.1016/j.cropro.2014.11.006.

PATEL, M.K. Technological improvements in electrostatic spraying and its impact to agriculture during the last decade and future research perspectives - a review. Engineering in Agriculture, Environment and Food, 2015. Available from: <http://www. sciencedirect.com/science/article/pii/S1881836615300173>. Online. Accessed: Dec. 20, 2015. doi: 10.1016/j.eaef.2015.09.006

RODRIGUES, A.C.P. et al. Evaluation of flat fan nozzles in spray deposition on different combinations of bean plants, Brachiaria plantaginea and Bidens pilosa. Planta Daninha, v.28, n.spe, p.1159-1171, 2010. Available from: <http://www.scielo.br/pdf/pd/ v28nspe/a24v28nspe.pdf $>$. Accessed: Dec. 20, 2015. doi: 10.1590/ S0100-83582010000500024.

SCHRÖDER, E.P. Pulverização eletrostática aérea: experiência e perspectivas no Brasil. Pelotas: Ed. do autor, 2002. 66p.

SCHRÖDER, E.P.; LOECK, A.E. Evaluation of aerial electrostatic spraying system in reducing application volume and dosage of herbicide glyphosate. Revista Brasileira de Agrociência, v.12, n.3, p.319-323, 2006. Available from: <http://www2.ufpel.edu.br/ faem/agrociencia/v12n3/artigo11.pdf>. Accessed: Jun. 25, 2015. doi: 10.18539/CAST.V12I3.4628.

SOCIEDADE SUL-BRASILEIRA DE ARROZ IRRIGADO (SOSBAI). Recomendações técnicas da pesquisa para o sul do Brasil. Gravatal, 2012. 176p.

ZHAO, S. et al. Factors affecting deposition in electrostatic pesticide spraying. Journal of Electrostatics, v.66, n.11-12, p.594-601, 2008. Available from: <http://www.sciencedirect.com/ science/article/pii/S0304388608000855>. Accessed: Dec. 21, 2015. doi: 10.1016/j.elstat.2008.06.009. 